\title{
The Effects of Storage on Sachet Water Quality in Ogun State, Nigeria
}

\section{OJEKUNLE, ZO ${ }^{1}$., OJEKUNLE, VO ${ }^{2}$., ERUOLA, AO ${ }^{1}$., OYEBANJI, FF ${ }^{1}$., OLATUNDE, $\mathrm{KA}^{1}$., AMUJO, BT ${ }^{1}$., SANGOWUSI, OR ${ }^{1}$ ADEKITAN, AA ${ }^{1}$., TAIWO, $\mathbf{A G}^{3}$}

\author{
${ }^{I}$ Federal University of Agriculture, Abeokuta, Ogun State. Nigeria \\ ${ }^{2}$ Institute of Rock and Soil Mechanics, Chinese Academy of Sciences. Wuhan. China \\ ${ }^{3}$ Moshood Abiola Polytechnic, Abeokuta. Ogun State. Nigeria \\ Corresponding Author: Ojekunle V.O. Email: rojeks@yahoo.com, ojekunlezo@funaab.edu.ng
}

\begin{abstract}
The purpose of this study is to investigate the effect of storage on the physicochemical status and bacteriological quality of sachet water produced and sold in Abeokuta metropolis, Nigeria. Ten brands of sachet water were collected within 24 hours of production and stored at ambient temperature. Sub-samples were drawn from the stock samples immediately for physico-chemical and microbiological analyses and after two months. Physical parameters were determined by instrumental methods. Cationic and anionic constituents were determined by standard titrimetric and spectrophotometric methods, trace and heavy water were determined by Atomic Adsorption Spectrophotometer. The study revealed that all the brands of water analyzed were physically and chemically wholesome and met the WHO standards. Five brands (50\%) of the water had total viable and coliform count above the recommended count of $100 \mathrm{cfu} / \mathrm{m}$ and zero $\mathrm{cfu} / \mathrm{ml}$, respectively. $\mathrm{pH}$ values increased in all brands to acceptable WHO limits within 2 months of storage except for sample 3 and 4 which decreases below the acceptable limit. Majorly dissolved oxygen and nitrate values decreased through the investigation period. Total and faecal coliform appeared in 50\% of sachet water samples analyzed immediately after production and were no longer detected after storing for two months except for sample 4. Results of the experiment indicate that $60 \%$ of the brands analyzed met the WHO guideline limit for drinking especially for the physico-chemical parameters while the majority failed in the microbiological essay when stored at ambient temperature for the two-month investigation period.
\end{abstract}

\section{http://dx.doi.org/10.4314/jasem.v19i2.3}

KEYWORDS: Coliforms, Conductivity, Microbiological Assay, Physical and Chemical Parameters, Turbidity, Sachet Water

\section{Introduction}

Water of good drinking quality is of basic importance to human physiology and man's continued existence depends very much on its availability. An average man (of $53 \mathrm{~kg}-63 \mathrm{~kg}$ body weight), requires about 3 litres of water in liquid and food daily to keep healthy (Wardlow et. al., 2004). This fact accounts for why water is regarded as one of the most indispensable substances in life. However, despite its relative abundance in some parts of the world, good quality drinking water is not readily available to consumers in some part of the globe. Unavailability of good quality drinking water is wide spread and this has serious health implications. Accessibility and availability of fresh clean water is a key to sustainable development and an essential element in for increase in good and food production (Adekunle et. al., 2004). However, an estimated 1.2 billion people around the world lack access to safe water and close to 2.5 billion persons are not provided with adequate sanitation (Third World Water Forum on Water, 2003). In developing nations of the world, $80 \%$ of all diseases and over $30 \%$ of deaths are related to drinking water (Dada and Ntukekpo, 1997). In 1988, a study funded by the National Endowment for the Humanities (NEH) investigated the interconnections among water supply and wastewater and solid waste collection and disposal in the United States and considered the broader intellectual context in which these services were devised and implemented to meet water demand. The resulting book, The Sanitary City, examined the development and implementation of these three services (Melosi, 2000). The NEH study and earlier research (Melosi, 1980) raised questions about the nature of the urban environment and the correlation between decisions to use certain kinds of "technologies of sanitation" and the prevailing public health and environmental views that inform those decisions. Though, given the Federal Ministry of Health statistics, only about 30\% of Nigerians have access to potable water, the United Nations estimated that about 1.2 billion people all over the world lack access to potable water (Oyeku et. al., 2001; Ajewole, 2005). 
To achieve such standards, raw water is subjected to purification processes that ranged from simple long term storage to enable sedimentation of suspended solids to aeration, coagulation, flocculation, filtration and disinfection among other treatments (Ajewole, 2005). The implication therefore, is that any drinking water sold to the public must be made wholesome and must meet WHO standards (Oyeku et. al., 2001). Unfortunately, the quality of water sold to the public in many places in Nigeria may not be wholesome (Mendie, 2004).

Every year, thousands of cholera cases are identified which trigger human fatalities in Nigeria. In addition, it has been confirmed in the country that waterrelated diarrhea is the most prevalent disease among the population after malaria, prompting the need for safe drinking (Njoku and Osinlu, 2007).

Hitherto, a number of small scale industries are packaging and marketing factory-filled sachet drinking water popularly called "pure water". This is considered by many as a safer source of potable water (Dodoo et. al., 2006).

Sachet water, a type of packaged water has, therefore, gradually become the most widely consumed liquid for both the rich and the poor in Nigeria. Sachet water is a kind of water which is abstracted from normal pipeline water supply (tap water) or borehole and is packaged into a transparent 50cl nylon bag but must have past through some or full conventional water treatment processes of abstraction, aeration, screening, flocculation, coagulation, sedimentation, filtration and chlorination. It is the brand of choice to everyone because it is a cheaper alternative to the bottled brand, considered to be the ideal drink of the affluent. Perceived hygiene, purity, taste, and, most importantly, safety are the reasons for sachet water consumption. Unfortunately, the problem of its purity and health concerns has begun to manifest (Oladipo et. al., 2009).

Sachet water is regulated as a food product in Nigeria by National Agency for Foods Drugs Administration and Control (NAFDAC). Sachet water is not completely sterile; it may not be entirely free of all infectious microorganisms. The potential danger associated with sachet water is contamination, which is a factor of the source of the water itself, treatment, packaging materials, dispensing into packaging materials and closure (Omalu et al., 2010). Under prolonged storage of packaged water at favorable environmental conditions, total aerobic heterotrophic bacteria can grow to levels that may be harmful to humans (Warburton et al., 1992).

The proliferation of sachet drinking water products raises the question as to whether they are hygienically produced; especially when the poor sanitary environment is coupled with irregular monitoring of sachet water producers by regulating agencies are seriously taken into account (Adekunle et. al., 2004; Obiri-Dansoet. al., 2003; Agada, 1998). Rutz (1996) reported that sachet water vending machine may not be free of microorganisms, because bacteria like Straptococcusfaecalis, have been isolated from sachet water producing machines.

According to the Institute of Public Health Analyst (IPAN), 50\% of the "pure water" sold in the streets of Lagos may not be fit for human consumption (Osibanjo et al., 2000). The possibility that the same situation may be applicable to other cities in the country prompted this work.

General Environment of Study Area: The study was carried out in Abeokuta, the capital of Ogun state and the traditional home of the Egbas. The Egba's have been traditionally divided into four ethnic subgroups namely; Egbaake, Oke- ona, Gbagura and Owu with each having its own king.

Geographically, Abeokuta lies in latitude $7^{\circ} 9^{\prime} 39^{\prime \prime} \mathrm{N}$ and longitude $3^{\circ} 20^{\prime} 54^{\prime \prime} \mathrm{E}$. The town is about $81 \mathrm{~km}$ south - west of Ibadan, Oyo state capital and $106 \mathrm{~km}$ north of Lagos state, former Nigeria capital city - see Figure 1. Abeokuta lies at an altitude of about $157 \mathrm{~m}$ above sea level amidst isolated outcrop of natural formation of granite rocks which give the towns landscape its undulating characteristics. The ancient and historic Olumo rock is a popular tourist and holiday resort in the town. Abeokuta as an area is known as the seat of large number of educational institutions. 


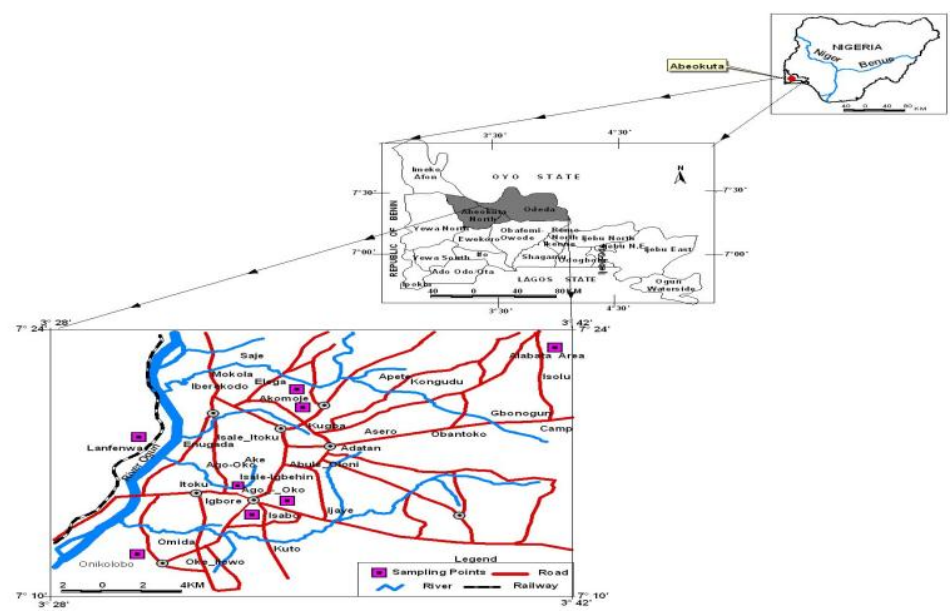

Fig 1: Road Map of Sample Collection Points in Abeokuta Metropolis of Ogun State, Nigeria

\section{MATERIALS AND METHOD}

Ten brands of sachet water with NAFDAC certification were randomly collected in different parts of Abeokuta in bags within 24hours of production and stored in a room at ambient temperature. Sub-samples were drawn from the stock samples in triplicates for physico-chemical characterization and bacteriological assay using APHA and EPA analytical methods (EPA, 1996; APHA, 2005).

Physico-chemical parameters of the sachet water were analyzed immediately after collection and subsequently after 8 weeks. Temperature, $\mathrm{pH}$, and dissolved oxygen of the sachet water were determined electrometrically with a multi-parameter data logger (Hanna model HI991300, Hanna Instruments, Singapore). The meter was calibrated prior to use with $0.01 \mathrm{~N}$ and $0.1 \mathrm{~N}$ standard potassium chloride solutions (according to the manufacturer's specifications), and buffer standards of $\mathrm{pH} 4$ and 7 at room temperature.

Total Suspended Solids and Turbidity: The total suspended solids (TSS) content and turbidity of each water sample were determined with the Hach portable colorimeter (Model DR/2000) as described by APHA (2005).

Conductivity: Conductivity was determined with a conductivity meter as described by APHA (2005) and determinations were done at $25^{\circ} \mathrm{C}$.

Determination of Anions; Chloride: Chloride was determined by the silver nitrate titrimetric method as described by APHA (2005).

Total Hardness: Total hardness was determined by the ethylenediaminetetra acetic acid (EDTA) titrimetric method as described by APHA (2005).

Sulphate, phosphate and Nitrate ions were determined using a calibrated DR/2000 spectrophotometer (Hach Company, Loveland, Colorado, USA), using appropriate pillow reagents and the required wavelengths.

Determination of Cations: Sodium, calcium and potassium ions were determined using flame photometry (APHA, 2005) methods. Iron was determined by a colorimetric method using Hach (modelDR/2000) colorimeter and "ferrover iron powder pillow reagent" as described by the Hachcolorimeter manual. Copper and zinc were similarly determined.

Alkalinity: Alkalinity in water samples was determined using the titrimetric procedure. (APHA, 2005)

Determination of Heavy Metals: Heavy metals such as Cadmium, Lead, Silver, Chromium and Nickel were determined by taking $50 \mathrm{ml}$ of each sample into a conical flask, $10 \mathrm{ml}$ of concentrated nitric acid $\left(\mathrm{HNO}_{3}\right)$ and $5 \mathrm{ml}$ of perchloric acid were added and mixed. The mixture was heated in the fume hood to near dryness and was allowed to cool before transferred into a measuring cylinder and later made up to $25 \mathrm{ml}$ with distilled water. The process is called "Digestion of Water for Metal Analysis". The solution called the digest was tested for the presence and concentration of the above mentioned metals using Atomic Absorption Spectrophotometer (AAS).

Microbiological Analyses: Chemicals reagents used according to manufacturer's specifications for the preparation of all the needed media, the standard plate count method was used for the analysis and subsequent serial doubling dilutions of the respective water samples were made.

The microbiological quality of the water samples was determined using total viable count and total coliform count as indices while total viable count was determined by the pour plate method.

Ten-fold dilution of the water sample was prepared and $0.1 \mathrm{ml}$ of the dilution was poured on nutrient agar

OJEKUNLE Z.O $O^{l}$, OJEKUNLE V.O O $^{2}$, ERUOLA A.O ${ }^{l}$., OYEBANJI F.F $F^{l}$., OLATUNDE K.A ${ }^{l}$., AMUJO B.T ${ }^{l}$, SANGOWUSI O.R ADEKITAN A.A ${ }^{l}$., TAIWO A.G $G^{3}$ 
plates and incubated at $37^{\circ} \mathrm{C}$ for 24 hours after which the plates were examined for growth after incubation. Total coliform count was determined on each sample by plating presumptive positive samples on Mac Conkayagar and then incubation was done at $35^{\circ} \mathrm{C}$ for 48 hours.

Statistical Analysis: The data obtained from the analysis of the water samples were subjected to one- way analysis of variance (ANOVA) while Duncan Multiple Range Test (DMRT) was used to determine the differences between the means.

\section{RESULTS AND DISCUSSION}

Table 1: Comparison of week 1 results with WHO standard, Table 2: Comparison of week 8 results with WHO standard

Table 1: Result of Physico-Chemical and Bacteriological Analysis of Week 1 with WHO Standard

\begin{tabular}{|c|c|c|c|c|c|c|c|c|c|c|c|}
\hline Parameters & Sample 1 & Sample 2 & Sample 3 & Sample 4 & Sample 5 & Sample 6 & Sample 7 & Sample 8 & Sample 9 & $\begin{array}{l}\text { Sample } \\
10\end{array}$ & Who standard \\
\hline Appearance & Colourless & Colourless & Colourless & Colourless & Colourless & Colourless & Colourless & Colourless & Colourless & $\begin{array}{l}\text { Colourles } \\
\mathrm{s}\end{array}$ & Colourless \\
\hline Temperature & 29.5 & 29.5 & 29.4 & 29.5 & 29.6 & 29.5 & 29.5 & 29.3 & 29.4 & 29.6 & $35-40^{\circ} \mathrm{C}$ \\
\hline $\mathrm{pH}$ & 6.0 & 6.4 & 6.6 & 6.8 & 6.9 & 6.8 & 6.9 & 7.0 & 7.0 & 7.0 & $6.5-8.5$ \\
\hline Odour & Odourless & Odourless & Odourless & Odourless & Odourless & Odourless & Odourless & Odourless & Odourless & Odourless & Odourless \\
\hline Conductivity & 0.40 & 0.42 & 0.41 & 0.36 & 0.30 & 0.42 & 0.39 & 0.41 & 0.50 & 0.42 & $1.0 \mathrm{mS} / \mathrm{cm}$ \\
\hline $\begin{array}{l}\text { Total Suspended } \\
\text { Solid }\end{array}$ & 6.0 & 5.0 & 4.0 & 4.0 & 5.0 & 6.0 & 4.0 & 0.0 & 0.0 & 12.0 & $30 \mathrm{mg} / \mathrm{l}$ \\
\hline Total Acidity & 3.0 & 2.0 & 2.0 & 2.0 & 2.0 & 2.0 & 2.0 & 2.0 & 2.0 & 1.0 & NS \\
\hline Total Alkalinity & 40.0 & 35.0 & 40.0 & 55.0 & 40.0 & 35.0 & 40.0 & 40.0 & 40.0 & 25.0 & $200 \mathrm{mg} / \mathrm{l}$ \\
\hline Total Hardness & 36.0 & 30.0 & 48.0 & 26.0 & 34.0 & 40.0 & 38.0 & 44.0 & 38.0 & 42.0 & $100 \mathrm{mg} / \mathrm{l}$ \\
\hline Chloride & 8.0 & 9.0 & 7.0 & 8.0 & 18.0 & 5.0 & 4.0 & 9.0 & 4.0 & 6.0 & $250 \mathrm{mg} / \mathrm{l}$ \\
\hline Nitrates & 3.6 & 3.8 & 2.4 & 1.4 & 1.4 & 2.8 & 0 & 2.0 & 1.8 & 7.6 & $10 \mathrm{mg} / 1$ \\
\hline Phosphate & 2.30 & 2.50 & 2.74 & 5.00 & 5.00 & 0.03 & 2.18 & 2.02 & 7.5 & 7.5 & $5 \mathrm{mg} / 1$ \\
\hline Sulphates & 20.0 & 33.0 & 28.0 & 18.0 & 18.0 & 25.0 & 30.0 & 21.0 & 30.0 & 36.0 & $250 \mathrm{mg} / 1$ \\
\hline Dissolved Oxygen & 7.13 & 6.93 & 6.93 & 6.93 & 6.75 & 6.89 & 6.64 & 7.21 & 7.21 & 6.80 & $2.0 \mathrm{mg} / 1(\mathrm{~min})$ \\
\hline Calcium & 0.45 & 0.34 & 0.29 & 0.35 & 0.39 & 0.30 & 0.33 & 0.31 & 0.25 & 0.20 & $200 \mathrm{mg} / \mathrm{l}$ \\
\hline Magnesium & 0.97 & 0.05 & 0.05 & 0.00 & 0.03 & 0.04 & 0.06 & 0.05 & 0.04 & 0.00 & $150 \mathrm{mg} / \mathrm{l}$ \\
\hline Sodium & 0.52 & 0.000 & 0.22 & 0.21 & 0.22 & 0.18 & 0.26 & 0.21 & 0.18 & 0.17 & $200 \mathrm{mg} / 1$ \\
\hline Potassium & 0.29 & 0.11 & 0.17 & 0.11 & 0.07 & 0.14 & 0.22 & 0.15 & 0.14 & 0.11 & $<20 \mathrm{mg} / 1$ \\
\hline Iron & 0.01 & 0.01 & 0.01 & 0.003 & 0.01 & 0.003 & 0.01 & 0.01 & 0.01 & 0.004 & $0.03 \mathrm{mg} / 1$ \\
\hline Cadmium & 0.00 & 0.0001 & 0.0001 & 0.0011 & 0.0011 & 0.00 & 0.0002 & 0.0002 & 0.0003 & 0.0013 & $0.002 \mathrm{mg} / 1$ \\
\hline Lead & 0.00 & 0.00 & 0.00 & 0.00 & 0.00 & 0.00 & 0.00 & 0.001 & 0.007 & 0.027 & $0.015 \mathrm{mg} / \mathrm{l}$ \\
\hline Chromium & 0.455 & 0.010 & 0.010 & 0.014 & 0.014 & 0.008 & 0.017 & 0.021 & 0.015 & 0.016 & $0.10 \mathrm{mg} / 1$ \\
\hline Total Plate Count & 45.0 & 80.0 & 20.0 & 60.0 & 100.0 & 80.0 & 100.0 & 100.0 & 100.0 & 100.0 & $100 \mathrm{cfu} / \mathrm{ml}$ \\
\hline $\begin{array}{l}\text { Total Coliform } \\
\text { Count }\end{array}$ & 0.00 & 28.0 & 0.00 & 240.0 & 0.00 & 0.00 & 920.0 & 240.0 & 140.0 & 0.00 & NIL \\
\hline $\begin{array}{l}\text { Confirmatory } \\
\text { Feacal Coliform } \\
\end{array}$ & Negative & Positive & Negative & Positive & NIL & Negative & Positive & Positive & Positive & NIL & Negative \\
\hline
\end{tabular}

Source: Author's Field Computation 2013

Note; sample 1- ORBDA, sample 2-BILCOM, sample 3-ADEKING, sample 4-ROYALMID, sample 5-I J, sample 6-BRIGHT STARS, sample 7-LADTOS, sample 8-ARCHIEVERS, sample 9-BAM, sample 10 - EGBA DOVE.

\begin{tabular}{|c|c|c|c|c|c|c|c|c|c|c|c|}
\hline PHYSICAL & SAMPLE 1 & SAMPLE 2 & SAMPLE 3 & SAMPLE 4 & SAMPLE 5 & SAMPLE 6 & SAMPLE 7 & SAMPLE 8 & SAMPLE 9 & $\begin{array}{l}\text { SAMPLE } \\
10\end{array}$ & $\begin{array}{l}\text { WHO } \\
\text { STANDARD }\end{array}$ \\
\hline Appearance & Colourless & Colourless & Colourless & Colourless & Colourless & Colourless & Colourless & Colourless & Colourless & Colourless & Colourless \\
\hline Temperature & 28.5 & 28.5 & 28.4 & 28.5 & 28.5 & 28.5 & 28.5 & 28.4 & 28.4 & 28.5 & $35-40^{\circ} \mathrm{C}$ \\
\hline $\mathrm{pH}$ & 7.2 & 7.1 & 5.5 & 5.3 & 6.7 & 7.4 & 7.4 & 7.1 & 7.4 & 6.7 & $6.5-8.5$ \\
\hline Odour & Odourless & Odourless & Odourless & Odourless & Odourless & Odourless & Odourless & Odourless & Odourless & Odourless & Odourless \\
\hline Conductivity & 0.45 & 0.50 & 0.44 & 0.48 & 0.55 & 0.60 & 0.40 & 0.53 & 0.57 & 0.49 & $1.0 \mathrm{mS} / \mathrm{cm}$ \\
\hline $\begin{array}{l}\text { Total } \\
\text { Suspended } \\
\text { Solid }\end{array}$ & 1.0 & 1.0 & 4.0 & 2.0 & 2.0 & 1.0 & 0 & 12.0 & 1.0 & 3.0 & $30 \mathrm{mg} / 1$ \\
\hline Total Acidity & 6.0 & 4.0 & 2.0 & 2.0 & 3.0 & 2.0 & 6.0 & 3.0 & 3.0 & 2.0 & NS \\
\hline $\begin{array}{l}\text { Total } \\
\text { Alkalinity }\end{array}$ & 45.0 & 50.0 & 40.0 & 65.0 & 35.0 & 50.0 & 40.0 & 45.0 & 35.0 & 40.0 & $200 \mathrm{mg} / \mathrm{l}$ \\
\hline Total Hardness & 42.0 & 56.0 & 62.0 & 42.0 & 60.0 & 52.0 & 76.0 & 70.0 & 42.0 & 50.0 & $100 \mathrm{mg} / \mathrm{l}$ \\
\hline Chloride & 9.00 & 9.00 & 11.00 & 11.00 & 10.00 & 10.00 & 8.00 & 9.00 & 9.00 & 9.00 & $250 \mathrm{mg} / 1$ \\
\hline Nitrates & 3.2 & 3.4 & 2.4 & 2.2 & 3.4 & 2.4 & 3.6 & 1.7 & 2.6 & 3.4 & $10 \mathrm{mg} / \mathrm{l}$ \\
\hline Phosphate & 0.82 & 0.78 & 0.49 & 1.65 & 0.84 & 0.34 & 0.57 & 0.87 & 0.88 & 0.65 & $5 \mathrm{mg} / 1$ \\
\hline Sulphates & 24.0 & 27.0 & 26.0 & 2.0 & 22.0 & 25.0 & 24.0 & 27.0 & 23.0 & 29.0 & $250 \mathrm{mg} / \mathrm{l}$ \\
\hline $\begin{array}{l}\text { Dissolved } \\
\text { Oxygen }\end{array}$ & 5.76 & 5.83 & 5.75 & 5.84 & 5.58 & 5.78 & 5.60 & 5.70 & 5.89 & 5.69 & $2.0 \mathrm{mg} / 1(\mathrm{~min})$ \\
\hline Calcium & 0.07 & 0.04 & 0.65 & 0 & 0.05 & 0.07 & 0.07 & 0.05 & 0.07 & 0.04 & $200 \mathrm{mg} / 1$ \\
\hline Magnesium & 0.20 & 0.10 & 0.15 & 0 & 0.09 & 0.17 & 0.17 & 0.14 & 0.18 & 0.11 & $150 \mathrm{mg} / \mathrm{l}$ \\
\hline Sodium & 0.07 & 0.04 & 0.05 & 0.08 & 0.04 & 0.05 & 0.05 & 0.05 & 0.06 & 0.04 & $200 \mathrm{mg} / \mathrm{l}$ \\
\hline Potassium & 0.04 & 0.02 & 0.03 & 0.04 & 0.01 & 0.03 & 0.03 & 0.02 & 0.03 & 0.02 & $<20 \mathrm{mg} / \mathrm{l}$ \\
\hline Iron & 0.0124 & 0.0040 & 0.0003 & 0 & 0.0004 & 0.0005 & 0.0036 & 0.0049 & 0.0009 & 0.0048 & $0.03 \mathrm{mg} / \mathrm{l}$ \\
\hline Cadmium & 0 & 0 & 0 & 0.0002 & 0 & 0.0003 & 0 & 0 & 0.0013 & 0.0074 & $0.002 \mathrm{mg} / \mathrm{l}$ \\
\hline Lead & 0 & 0 & 0 & 0 & 0 & 0 & 0 & 0 & 0 & 0.0008 & $0.015 \mathrm{mg} / 1$ \\
\hline Chromium & 0.0011 & 0.0004 & 0.0006 & 0.0012 & 0.0001 & 0.0004 & 0.0015 & 0.0003 & 0.0008 & 0.0001 & $0.10 \mathrm{mg} / \mathrm{l}$ \\
\hline $\begin{array}{l}\text { Total Plate } \\
\text { Count }\end{array}$ & 60 & 30 & 50 & 40 & 20 & 20 & 50 & 2 & 0 & 0 & $100 \mathrm{cfu} / \mathrm{ml}$ \\
\hline $\begin{array}{l}\text { Total Coliform } \\
\text { Count }\end{array}$ & NIL & NIL & NIL & 13 & NIL & NIL & NIL & NIL & NIL & NIL & NIL \\
\hline $\begin{array}{l}\text { Confirmatory } \\
\text { Feacal } \\
\text { Coliform }\end{array}$ & NIL & NIL & NIL & Positive & NIL & NIL & NIL & NIL & NIL & NIL & Negative \\
\hline
\end{tabular}


Table 2: Result of Physico-Chemical and Bacteriological Analysis with WHO Standard Source: Author's Field Computation 2013

Note; sample 1- ORBDA, sample 2-BILCOM, sample 3-ADEKING, sample 4-ROYALMID, sample 5-I J, sample 6-BRIGHT STARS, sample 7-LADTOS, sample 8-ARCHIEVERS, sample 9-BAM, sample 10 - EGBA DOVE.

Table 1 and 2 present the results of the physical, chemical and bacteriological characteristics of the sachet water samples in the initial first week and after eight weeks of storage. All the samples were colourless while odour and taste were objectionable as observed by many consumers.

The mean range values of $\mathrm{pH}$ for the week 1 and week 8 of storage were (6.00-8.00 and 5.30-7.40) respectively and were within the acceptable minimum range of 6.5-8.5 specified by WHO (2011) except that some of the samples in week 8 of storage had lower $\mathrm{pH}$ values. The $\mathrm{pH}$ values obtained signified majority were slightly alkaline and such water samples were unlikely to cause health problems such as acidosis as revealed by previous work done by Asamoah and Amorin, 2011. However, this $\mathrm{pH}$ do play significant role in determining the bacterial population growth and diversity in sachet water. Increase in the observed $\mathrm{pH}$ could be attributed to the production of basic metabolic waste products by increasing bacterial population. In their review, Prescott et al. (1999) stated that microorganisms frequently change the $\mathrm{pH}$ of their own habitat by producing acidic or basic metabolic waste products.

The temperature values of the sachet water samples as presented above showed values ranged from 29.30 to $29.60^{\circ} \mathrm{C}$ (week 1) and $28.40-28.6^{\circ} \mathrm{C}$ (week 8). The temperature values obtained throughout the investigation period were within the acceptable optimal growth range for mesophilic bacteria including human pathogens.

Conductivity values express the amount of dissolved solids in the water sample, sachet water sold in Abeokuta town has conductivity values that ranged from $0.30-0.50 \mathrm{mS} / \mathrm{cm}$ at $25^{\circ} \mathrm{C}$ (week 1) and 0.35 $0.65 \mathrm{mS} / \mathrm{cm}$ at $25^{\circ} \mathrm{C}$ (week 8). Conductivity of the water sampled were within the acceptable standard recommendation of $1.0 \mathrm{mS} / \mathrm{cm}$ at $25^{\circ} \mathrm{C}$ by $\mathrm{WHO}$ and NAFDAC.

The total suspended solids values varied significantly amongst the samples and these variations may be attributed to further filtration processes and packaging that the raw water was subjected to given the fact that most processors got their raw water from Ogun State Water Corporation.

All sachet water sampled for the for week 1 and 8 met the recommended WHO/NAFDAC standards in terms of its physical characteristics or parameters.

The dissolved oxygen mean values obtained for the sachet water samples ranged from 6.64-7.21 mg/l (week 1) and 5.58-5.89mg/l (week 8) and this could be attributed to the growth of aerobic and facultative anaerobic bacteria which enhances the presence of dissolved oxygen in sachet water. A decrease in dissolved oxygen was generally observed in all sachet water samples throughout the investigated storage period; an indication of possible bacterial degradation of organic materials by the bacterial flora.

The chemical characteristics of all the brands of water evaluated were within the acceptable maximum range of standard concentration values recommended by WHO and NAFDAC for chloride, total hardness, phosphate, nitrate, sulphate, iron, potassium, sodium and calcium. The implication of these results is that the processors of these brands of water abstracted raw water from chemically good sources and adopt standard operating procedures for chemical water treatment.

Sample 3 and sample 4 had the highest and lowest values of $48 \mathrm{mg} / \mathrm{L}$ and $26 \mathrm{mg} / \mathrm{L}$ of total hardness expressed as $\mathrm{CaCO}_{3}$ in week 1 , respectively while that of week 8 , sample 7 and 4 had the highest and lowest values of $76 \mathrm{mg} / \mathrm{L}$ and $0 \mathrm{mg} / \mathrm{L}$ of total hardness, respectively. However, the level of total hardness in all the brands of water evaluated for the period of investigation is within the maximum acceptable range for total hardness of $100 \mathrm{mg} / \mathrm{L}$ recommended by WHO and NAFDAC.

The mean levels of other anions, phosphate, nitrate and sulphate in all the brands of water evaluated met the recommended standards for potable water.

Amongst the samples in week 1, samples 9 and 10 had the highest mean concentration of phosphate (7.5 $\mathrm{mg} / \mathrm{L})$ which exceeded the WHO limit $(5.0 \mathrm{mg} / \mathrm{L})$ and sample 6 had the lowest $(0.03 \mathrm{mg} / \mathrm{L})$. In week 8 after storage, the mean concentration of sample 4 had the highest value $(1.65 \mathrm{mg} / \mathrm{L})$ while sample 6 had the lowest of $0.34 \mathrm{mg} / \mathrm{L}$. The values of nitrate ranged from $0-7.60 \mathrm{mg} / \mathrm{L}$ and $1.70-4.0 \mathrm{mg} / \mathrm{L}$ in week 1 and 8 after storage, respectively. The result also indicated a decreased Nitrate values in most of the samples throughout the investigation period while this decrease in nitrate values could be attributed to its utilization by microorganisms for growth and reproduction (Prescott et. al., 1999)

There were variations in the levels of the cations; iron, potassium, sodium and calcium in the different brands of water evaluated.

The level of total iron in the water samples ranged in week 1, from 0.0031-0.0140 mg/L and 0-0.0124

OJEKUNLE Z.O ${ }^{l}$., OJEKUNLE V..$^{2}$., ERUOLA A.O $O^{l}$., OYEBANJI F.F ${ }^{l}$., OLATUNDE K.A ${ }^{l}$., AMUJO B.T ${ }^{l}$, SANGOWUSI O.R ADEKITAN A.A ${ }^{l}$., TAIWO A.G $G^{3}$ 
$\mathrm{mg} / \mathrm{L}$ in week 8 respectively, these values were below the maximum limit of $0.30 \mathrm{mg} / \mathrm{L}$ for total iron recommended by WHO (2011).

Heavy metals:The results of the samples both in week 1 and 8 indicated that the concentration of selected metals present (Lead, Cadmium, Chromium, Manganese) were at concentrations below the WHO limits and had little or no significance except for sample 10 in week 8 where cadmium was found to $0.0074 \mathrm{mg} / \mathrm{L}$ as against the $0.002 \mathrm{mg} / \mathrm{L}$ WHO limits. Other metals (Zinc, Copper, Aluminium, Manganese, Nickel, Cobalt, Arsenic, Mercury and Silver) were below the detectable limits of the metals.

Bacteria: Total coliform bacteria were detected in $50 \%$ of the brands of sachet water analyzed within the first week while faecal coliforms were detected in $50 \%$ of the brands of sachet water analyzed at the onset of the investigation. However, total coliforms and faecal coliforms were not detected after the 8 week storage period except in sample 4 which had $13 \mathrm{cfu} / \mathrm{ml}$ coliform bacteria and tested positive for faecal coliform. The significant of this no coliform after some weeks of water production is because indicator organisms loose viability during storage over time (WHO, 2001).

Total coliforms are widely used as indicators of the general sanitary quality of treated drinking water while faecal coliforms give a much closer indication of faecal pollution (Ashbolt et. al, 2001) and consequently, WHO limit is that none should be detected by any means.

The majority of the sachet water samples analyzed one week after production did exceed WHO limit of $100 \mathrm{cfu} / \mathrm{ml}$ for total bacteria. Total bacteria appeared in $50 \%$ of sachet water samples analyzed after first week and died off with passage of storage except in sample 4 which had $13 \mathrm{cfu} / \mathrm{ml}$ coliform bacteria and tested positive for faecal coliform in week 8 (after two months of storage). Although sample 4 is the only sachet water produced from a borehole source in this study, and that reaffirms the result of study done by Okoli et al., (2005), indicating that the boreholes can be heavily contaminated with faecal matter. Feacal contamination of drinking water has very serious health implications (Banwart, 2004) and the source of these contaminations can be attributed to the deliberate and indiscriminate littering of human and animal waste in adjoining bushes proximal to the borehole sites.

Conclusion: The analytical results revealed that prolonged storage caused an increase in $\mathrm{pH}$. The study also confirmed that presence of dissolved oxygen coupled with availability of organic material and nutrients aided continuous and rapid proliferation of bacteria in the sample of sachet water tested over time.

It was evident from the study that sachet water sampled in Abeokuta metropolis at the first week of production met the recommended standards for physical and chemical qualities but about $75 \%$ of the water brands were microbiologically unwholesome as the bulk of sachet water brands were contaminated by coliform bacteria and such coliform bacteria die off later as the storage time increases (approximately 8 weeks). It is therefore necessary for sachet water to be properly treated and consume as soon as possible to meet the WHO standard for drinking water. Since microbiological quality of water is a hidden attribute that impact seriously on public health, it is pertinent that the activities of regulatory agencies be intensified to ensure compliance with standard to avert public health hazards.

Most sachet water producers also failed to comply with the National Agency for Food, Drug, Administration and Control (NAFDAC, Nigeria) guidelines by depending solely on tap water as its major source. Tap water although potable in some instance may be undesirable for packaging as sachet water 'pure water' due to the addition of chlorine in the treatment process as water sealed for certain period of time before consumption might not be free from chlorine residual which are hazardous to the health.

Recommendations: The expiration date of sachet water produced in Nigeria should not exceed four weeks from the date of production. The public should be informed not to drink sachet water that has exceeded four weeks from the date of production. The regulatory body should promulgate standardized methods of storage of sachet water in order to increase its shelf life. Periodic sanitary inspection of sachet water factories by the regulatory body is absolutely necessary to ensure conformity and finally, the mandatory production date must be sealed on the body of the sachet of water for the end user to see so as to informed their purchase and consumption.

\section{REFERENCES}

Adekunle, L.V.; Sridhar, M.K.C.; Ajayi, A.A.; Oluwade, P.A. and Olawuyi, J.F., 2004. An assessment of the health and social economic implications of sachet water in Ibadan, Nigeria: A public health challenge. Afr. J. Biochem. Res., 7: 5-8.

Agada, O.A., 1998. Result of baseline studies on water supply and sanitation conducted by Federal Ministry of Water Resources and Rural Development, Nigeria: UNICEF assisted National Water Supply and Sanitation Monitoring Programme-An Overview.FGN-UNICEF WEB Review Meeting, pp: $1-14$ 
Ajewole, I.A., 2005. Water an Overview, Food Forum, A Publication of the Nigerian Institute of Food Science and Technology, 4(1): 15

APHA, 2005.Standard Methods for the Examination of Water and Wastewater. $20^{\text {th }}$ Edn., American Public Health Association, Washington D.C., U.S.A.

Asamoah, D.N. and Amorin, R., 2011. Assessment of thequality of bottled/sachet water in theTarkwaNsuaem municipality (TM) of Ghana.Res. J. Appl. Sci. Eng.Technol., 3(5):377-385.

Banwart, G.J., 2004. Basic Food Microbiology,2nd ed. Chapman \& Hall Inc.,NewYork,751 pp.

Dada, A. and Ntukekpo, D.S., 1997. Pure Water: How Safe? Ultimate Water Technology and Environment, 1(3): $8-11$.

Dodoo, D.K.; Quagraine, E.K.; Okai-Sam, F.; Kambo, D.J. and Headley, J.V., 2006. Quality of "sachet" waters in the Cape Coast municipality of Ghana. J. Environ. Sc. Health: Part A, 41: 329-342.

EPA 1996. Complication of EPA's Sampling and Analysis Methods.U.S.Environmental Protection Agency. Keith, L. H. (Ed), 2nd Edition. Lewis Publishers. USA, pp. 1696.

Melosi, M.V., 1980. Environmental Crisis in the City: The Relationship Between Industrialization and Pollution. Pollution and Reform in American Cities, 1870-1930, University of Texas Press, Austin

Melosi, M.V., 2000. The Sanitary City: Urban Infrastructure in America From Colonial Times to the Present. The Johns Hopkins University Press, Baltimore.

Mendie, U., 2004. Cyclical Growth of Contaminants in Drinking Water Packaged in Polythene Bags.Nigerian Journal of Pharmacy 40: 398 - 399.

Njoku, G and Osondu, A., 2007. New Standard for Drinking Water Quality in Nigeria to Ensure the Safety of Drinking Water and Protect Public Health. http://www.unicef.org/Nigeria/wash-2165.html

NRC. 1989..National Research Council, Food andNutrition Board. Recommended Dietary Allowances, 10th ed. Washington, D.C.National Academy of Sciences.

Obiri-Danso, K. A.; Okore-Hanson and Jones K., 2003. The microbiological quality of drinking water sold on the streets in Kumasi, Ghana. Lett. Appl. Microbiol., 37: 334-339.
Okoli G.; Chidi I.V.; Njoku N.; Chukwuocha A.C.; Njoku P.C.; and Njoku J.D., 2005. Quality Characteristics of Groundwater Utilized By Resident Students of a Nigerian University

Oladipo I. C.; Onyenike, I.C.; and Adebiyi, A. O., 2009. Microbiological analysis of some vended sachet water in Ogbomoso, Nigeria. African J of Food Sci., 3(12): $406-412$

Omalu, I.C.J.; Eze, G.C.; Olayemi, I.K.; Gbesi, S.; Adeniran, L.A.; Ayanwale, A.V.; Mohammed, A.Z.; and Chukwuemeka, V., 2010. Contamination of Sachet Water in Nigeria: Assessment and Health Impact. Online $J$ of Health and Allied Sci., $9(1): 1-3$.

Osibanjo, O.; Ajayi, S.; Adebiyi, F. and Akinyanju, P., 2000.Public Analysis Reporting System as Applied to Environmental Issues. IPAN News, A Publication of the Institute of Public Analysts 1(3):10.

Oyeku, O.M.; Omowumi, O.T.; Kupoluyi, C.F. and Toye, E.O., 2001. Wholesomeness Studies of Water Produced and Sold in Plastic Sachets (Pure Water) in Lagos Metropolis. Nigerian Food Journal,19:63- 69.

Prescott L M, Harley J P. and Klein D. A. 1999. The influence of environmental factors on growth. Microbiology.4th Edition. McGraw-Hill Companies, Inc., USA, pp. 123-132.

Rutz, D., 1996. Pure water vending machines may not be so pure. CNN: Food \& Health, May 2.

Tay, C..K., 2007. Chemical characteristics of groundwaterin the Akatsi and Ketu Districts of the Volta Region,Ghana. West Afr. J. Appl. Ecol., 11: 123

Third World Water Forum on Water, 2003.Blockade, Myth, Illusions in Development and Cooperation. Tokyo, Japan, Vol. 30.

Warburton, D. W.; Dodds, K. L.; Burke, R.; Johnston, M. A and Laffey P. J., 1992. A review of the microbiological quality of bottled water sold in Canada between 1981 and 1989. Can. J. Microbiol.,38:12-19.

WHO, 2011. Guidelines for Drinking-Water Quality. Word Health Organisation, Geneva, Switzerland

Wordlaw, G.M.; Hampl, J.S. and Disilvestro, R.A., 2004. Perspectives in Nutrition. 6th ed. McGraw-Hill Publishers, New York, pp.372 - 412. 